\title{
Troblems in Artificial
}

\section{Recharge Through Wells}

in the Grand Prairie

\section{Region, Arkansas}

B, R. T. SNIEGOCKI

ARTIFICIAL RECHARGE OF GROUND WATER-GRAND PRAIRIE REGION, ARKANSAS

FELOGICAL SURVEY WATER-SUPPLY PAPER 1615-F

Prepared in cooperation with the

U.S. Army Corps of Engineers, and the Agricultural Experiment i'tation, University of Arkansas

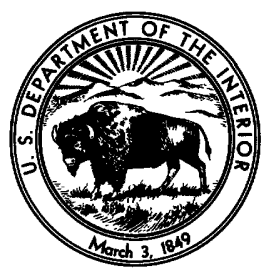




\title{
UNITED STATES DEPARTMENT OF THE INTERIOR
}

STEWART L. UDALL, Secretary

\author{
GEOLOGICAL SURVEY
}

Thomas B. Nolan, Director 


\section{CONTENTS}

Abstract

Introduction

Purpose of this report._.

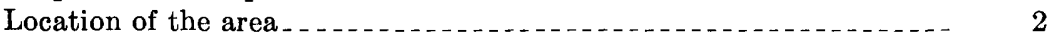

Acknowledgments_._._.

Problems when recharging through wells _._.

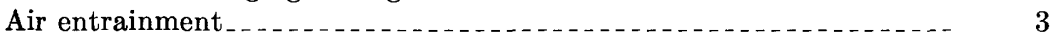

Water temperature and viscosity _...... 8

Suspended material in water _...

Micro-organisms_._.

Interpretation of recharge data $\ldots \ldots \ldots \ldots \ldots \ldots$

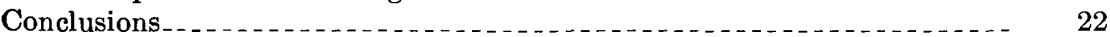

References cited $\ldots \ldots \ldots \ldots$

\section{ILLUSTRATIONS}

Plate 1. Arithmetic plots of the water levels inside the recharge well and in an observation well 5 feet from the recharge well during test $13 \ldots$

Frgure 1. Map of Arkansas showing the location of the Grand Prairie region

2. Graph of water levels showing the effect of air entrainment.-

3. Hydrograph of the recharge well during test $12 \ldots$

4. Hydrograph of the recharge well during test 18..........

5. Idealized sketch of a typical well in the Grand Prairie region, Arkansas

Page

6. Graphs showing the depths to water inside and immediately outside the recharge well, the injection rate, and the turbidity of the injected water during recharge tests 8 and 9.

7. Graph showing the difference in injection heads inside the recharge well caused by turbidity during tests 8 and $9 \ldots \ldots$

8. Hydrograph of the water level in an observation well 200 feet

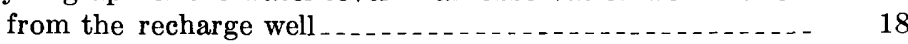

9. Logarithmic plot of $s_{0}$ versus $r^{2} / t$ during test $13 \ldots \ldots$

10. Theoretical hydrographs of water levels in a recharge well in the Grand Prairie region, Arkansas................. 



\title{
ARTIFICIAL RECHARGE OF GROUND WATER- GRAND PRAIRIE REGION, ARKANSAS
}

\section{PROBLEMS IN ARTIFICIAL RECHARGE THROUGH WELLS IN THE GRAND PRAIRIE REGION, ARKANSAS}

\author{
By R. T. SNIEgOCKI
}

\begin{abstract}
Most of the problems of recharge through wells involve clogging of the well and aquifer. In this study, the principal causes of clogging were air entrainment, suspended particles in the recharge water, and micro-organisms. Other problems in operating a recharge well included the effects of injecting water with a high viscosity and the interpretation of water-level changes in the aquifer during recharge tests. The results of this investigation indicate that wells should be recharged with treated water. Water-treatment cost and contemplated use of the reclaimed water are the principal factors involved in determining the economic feasibility of artificial recharge.
\end{abstract}

\section{INTRODUCTION}

The Grand Prairie region of Arkansas was selected for an investigation of the fundamental principles of artificially recharging groundwater reservoirs in alluvial deposits through wells, because this region of Quaternary sand and gravel appeared to provide a large natural laboratory in which studies of general interest could be conducted. Irrigation pumping has dewatered the Quaternary sediments in a large part of this region and has created a situation ideal for experiments on artificial recharge through wells. It has produced also a water-supply problem for the rice farmers and others living in the area.

The study involved carefully controlled experiments to determine the feasibility of artificial recharge using various types of wells and waters. Recharge through wells would be most economical if surface water could be introduced directly into the dewatered part of the Quaternary aquifer without the expensive pretreatment considered essential for artificial recharge through wells. 


\section{PURPOSE OF THIS REPORT}

This report is one of a series covering distinct elements of project work which have been prepared and released as the data and interpretative analyses became available. The purpose of this report is to discuss some of the factors that caused difficulty when injecting water through a well.

\section{LOCATION OF THE AREA}

The Grand Prairie region in east-central Arkansas is in the physiographic province of the United States known as the Coastal Plain. The region is an irregular but continuous tract of prairie lying between the White River and Bayou Meto. It extends northwestward, from near the confluence of the White and Arkansas Rivers, to a short distance beyond Lonoke, Lonoke County. Nearly all Arkansas County and parts of Lonoke, Prairie, and Monroe Counties are included in the Grand Prairie region (fig. 1).

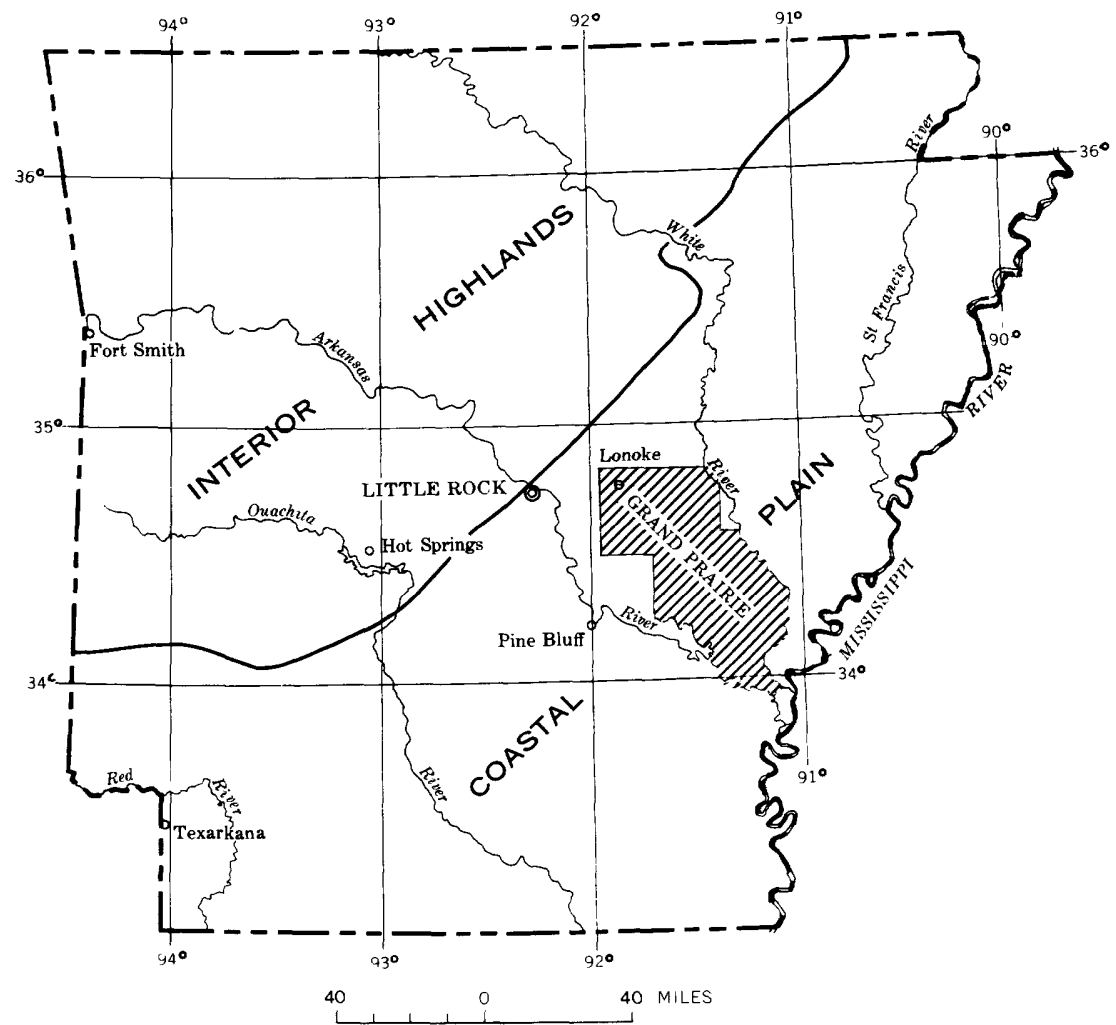

FIGURD 1.-Map of Arkansas showing the location of the Grand Prairie region. 


\section{ACKNOWLEDGMENTS}

The U.S. Army Corps of Engineers and the University of Arkansas actively participated with the U.S. Geological Survey in the studies. These three agencies were the principal ones responsible for the experiments, but they were assisted by the State Health Department, the Arkansas Geological and Conservation Commission, the Stuttgart Chamber of Commerce, and other local agencies, companies, and individuals.

A detailed account of assistance is listed in chapters A and B of Water-Supply Paper 1615 (Engler and others, 1963; Sniegocki, 1963a).

\section{PROBLEMS WHEN RECHARGING THROUGH WELLS}

The principal causes of clogging mentioned in reports concerning recharge through wells are:

1. Suspended particles in the recharge water.

2. Bacterial contamination of the aquifer by the recharge water and subsequent clogging by bacterial growths.

3. Chemical reactions between the ground water and recharge water, causing precipitation of insoluble products.

4. Mechanical jamming of the aquifer, caused by particle rearrangement when the direction of water movement through the aquifer is reversed.

5. Swelling of clay colloids in the aquifer.

6. Ion-exchange reactions that could result in clay-particle dispersal.

7. Precipitation of iron in the recharge water as a result of aeration.

8. Biochemical changes in the recharge water and ground water involving ironreducing bacteria or sulfate-splitting organisms.

9. Gas binding or air entrainment in the aquifer.

Nearly all these factors may have caused some degree of clogging during one or more of the recharge tests made during this study. In addition, water temperature and viscosity influenced recharge results. Chemical reactions (items $3,5,6$, and 7 ) potentially are a serious cause of well clogging, but they have received the least consideration and are poorly described in most recharge literature. A previous report in this series discusses the geochemical data collected during this study (Sniegocki, 1963b).

\section{AIR ENTRAINMENT}

To determine properly the least treatment that can be given a recharge water and still permit injecting the water with a minimum of technical difficulties, it is desirable to isolate each cause of clogging that may occur and quantitatively evaluate its effect. Obviously, the first cause of clogging to be isolated should be the one that plugs the 
recharge well or aquifer rapidly and most severely. Air entrainment was the most serious cause of plugging in recharge tests made in the Grand Prairie region.

Air entrainment was a major cause of clogging in the recharge well because of the arrangement of the water-treatment equipment. Conventional water-treatment practices, such as coagulation and settling with alum, chlorination, and filtration through a rapid-sand filter, were used with variations during a series of recharge tests. Initially, the filter-effluent pipe was connected directly to the intake pipe of the recharge well. It developed that the pipes operated as a siphon, creating pressure gradients through the filter that destroyed its effectiveness. A vertical standpipe about 3 feet high and a control valve were installed in the well-intake pipe between the filter and the well. By opening the valve during periods of recharge, the siphon head was prevented from operating on the filter. However, large quantities of air entered the standpipe, mixed with the recharge water, and were carried to the inner face of the well screen and through the screen into the aquifer.

The clogging effect of air entrainment may be illustrated best by comparing water-level measurements made during a recharge test in which air was admitted to the intake pipe with water-level measurements made during a test in which air was excluded. This comparison is valid only because the variables such as the recharge rate, time at which water-levels were measured, recharge-water treatment, and hydrologic conditions were alike. An arithmetic plot of water-level data for two recharge tests is shown in figure 2 .

The upper set of curves is drawn from water-level data collected during recharge with the 4-inch valve open. The lower set is drawn from water-level data collected during recharge in a closed system. The upper curves, in descending order, show rises in water level averaging about $2.0,1.7$, and 0.3 feet per hour, whereas the lower curves show rises averaging only $0.06,0.06$, and 0.04 foot per hour. The buildup of head in the observation well 5 feet from the recharge well was about 8 times greater when the injected water contained air. This increase in rate of buildup of the water level reflects a rapid decrease in the permeability of the aquifer near the well. The water level inside the recharge well rose about 30 times faster during injection of water containing air. A part of this difference in rate of rise is attributed to decreased permeability of the aquifer near the well and a part to decreased permeability of the well screen itself.

The lower set of curves shows a head difference of 0.0 to 0.2 foot between the water level inside the recharge well and the water level immediately outside. The upper set of curves shows a head difference of 7 to 9 feet. A comparison of the curves (fig. 2) indicates that con- 

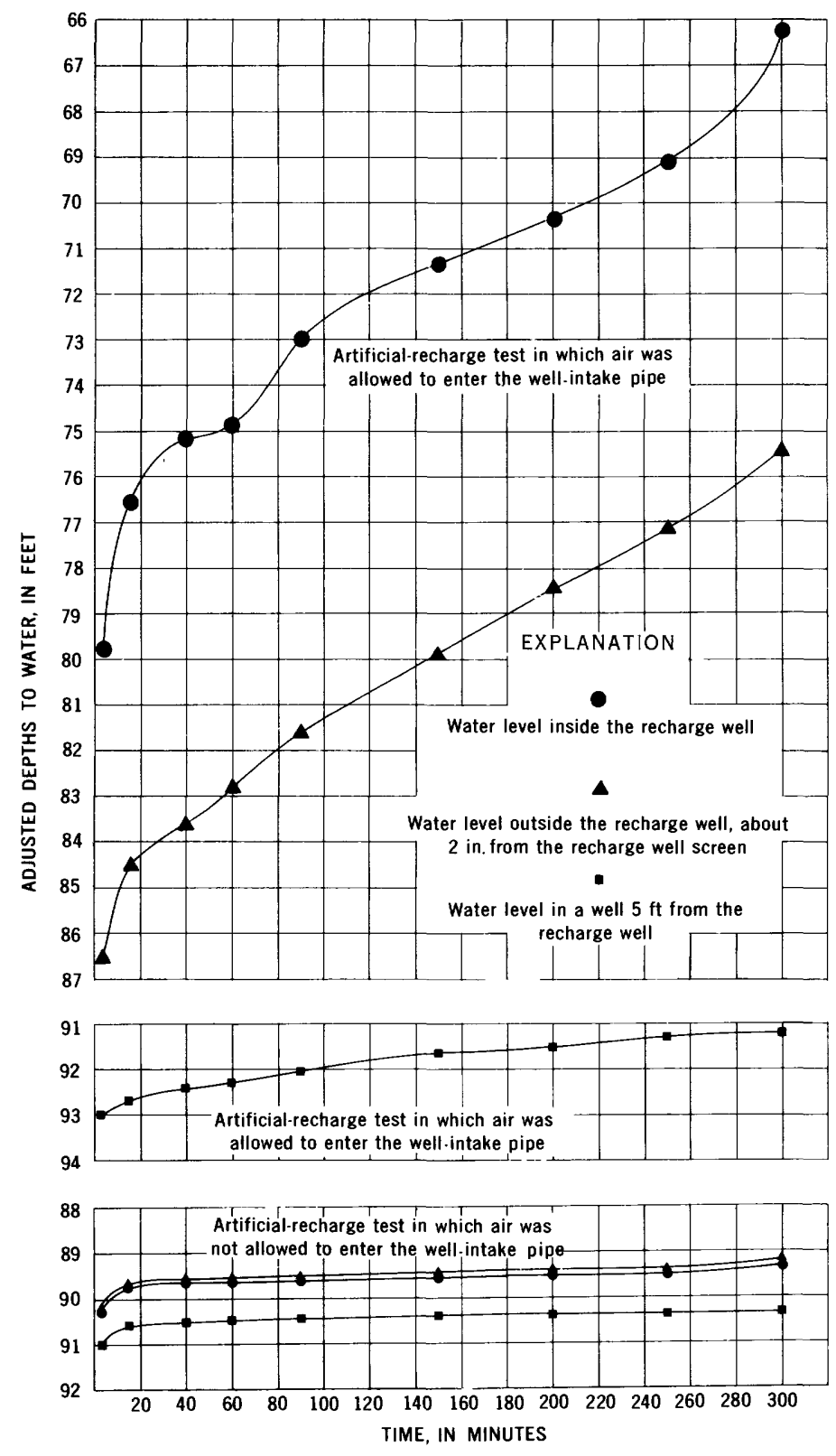

Figure 2.-Graph of water levels showing the effect of air entrainment during recharge. 
siderable clogging of the well screen number 12 brass wire by air occurred during injection of water containing air. Further evidence of clogging of the screen by air is indicated by the fact that during the decay of the cone of elevation, after injection of water containing air bubbles, the difference in head inside and outside the well dissipates and approaches that exhibited by the lower set of curves. Apparently, the air entrained on the screen face escapes to the surface of the water in the well or is carried into the aquifer and is not replaced after injection stops.

Comparisons of the apparent values of aquifer transmissibility and specific capacities of wells, indicated by the hydraulic data for the "air" and "no air" tests, show a permeability reduction of at least 50 percent when air was entrained. The amount of air permitted to enter the well-intake pipe was virtually the same in the earlier recharge tests involving air entrainment. In later tests an attempt was made to determine whether the reduction of permeability of the aquifer was proportional to the quantity of air allowed to enter the intake pipe.

To determine the effect of varying amounts of air entering the recharge-well supply pipe, a $1 / 2$-inch valve was installed in addition to the 4-inch valve in the pipe to control the size of the entrance orifice. No change in the shape of the hydrographs drawn from water-level measurements made in and around the recharge well could be correlated with changes in the size of the opening admitting air to the injected water. Opening the $1 / 2$-inch valve seemed to plug the well and aquifer as severely as opening the 4 -inch valve. If a correlation exists between the volume of air entrained and the degree of plugging, it would involve quantities of air smaller than the least amount that was admitted through the $1 / 2$-inch valve.

To determine whether the air entrained in the aquifer dissipated after a period of time, no well redevelopment was done after a test in which the well and aquifer were deliberately plugged by air entrainment. Short specific-capacity tests were made at intervals for 9 weeks after injection. The specific capacity of the recharge well was $25 \mathrm{gpm}$ per $\mathrm{ft}$ before injection and $12 \mathrm{gpm}$ per ft immediately afterwards. During the 9 -week period 5 determinations of the well's specific capacity were made. No increase in specific capacity was noted. The maximum yield of the well after being plugged by air, without breaking pump suction, was 200 to $250 \mathrm{gpm}$, whereas before plugging the well yielded about $500 \mathrm{gpm}$. Apparently, the air entrained in the aquifer dissipated slowly with simple pumping of the well. Special redevelopment procedures involving the use of sodium hexametaphosphate and surging and pumping were necessary before the specific capacity of the well was restored.

Aeration and subsequent precipitation of any iron in the ground water or injected water would tend to clog the well and aquifer. Gen- 
erally, the surface-water supply used for injection has a low iron content, 0.00 to $0.7 \mathrm{ppm}$, whereas the ground water in the project area contains 0.1 to $2.6 \mathrm{ppm}$. Data are not available regarding secondary plugging effects that could be caused by air introduced into the aquifer.

The exact manner in which air bubbles become lodged in the interstices of the aquifer during these tests is not known. Forces that exceed the buoyancy of the air bubbles and the pressure of the injected water are assumed to exist and to prevent the movement of the bubbles outward from the well or upward to the water table. The bubbles have the same effect as clay particles or sand grains and effectively retard the passage of water. The forces that resist movement of the bubbles may result from at least one or more of three causes: (1) Simple blocking of the air bubbles by sand grains, (2) a phenomenon called the Jamin effect (Smith and Crane, 1930), and (3) distortion of gas bubbles when they are forced through the capillary openings (Gardescu, 1930; and Orlob and Radhakrishna, 1958). The principle of the phenomenon called the Jamin effect is that a capillary tube containing restrictions and filled with a chain of alternate air and water bubbles is capable of sustaining a finite pressure. The pressure that can be sustained is determined largely by the degree of wetting of the capillary tube, contamination of the inner surface of the tube, the number of air bubbles in the chain, the surface tension of the water, and the distortion of gas bubbles when forced through capillary openings. The aquifer probably acts as a series of interconnected capillary tubes containing many restrictions, and the forces created by the Jamin effect and bubble distortion act to prevent the movement of the entrained air once it has been introduced into the aquifer.

To eliminate the siphon effect on the filter and exclude air from the well-intake pipe, a clear well (Sniegocki, Bayley, and Engler, 1963) was installed which received the filter effluent and from which the effluent was siphoned into the recharge well. No air can enter the system from the atmosphere as long as leaks do not develop in the intake pipe. Also, recharge under constant-head conditions with the water level in the well at the land surface or installation of a valve at the bottom of the injection pipe would minimize air entrainment. The elimination of siphon effects during recharge is discussed in detail in U.S. Geological Survey Water-Supply Paper 1615-D (Sniegocki and Reed, 1963).

Another possible source of air or other gases exists that may be more difficult to control. Gases may be liberated from solution in the recharge water if it is warmed by contact with the ground water and the aquifer. Heat might be generated also by biological decomposition of suspended organic matter in the injected water (California Water Pollution Control Board, 1954, p. 142). No data were collected regarding this aspect of gas binding in the aquifer. Generally, the 
temperatures of the injected water and the ground water were nearly the same and chlorination prevented most biological decomposition.

\section{WATER TEMPERATURE AND VISCOSITY}

The effects of water-viscosity variations caused by differences in water temperatures were investigated during two recharge tests. The temperature of the native ground water before the tests started was $65^{\circ} \mathrm{F}$, but the temperature of the injected water was different in the two tests.

Test 12, utilizing a gravel-packed recharge well, was started on October 11, 1957. Surface water from a reservoir was treated with copper sulfate as a micro-organism-control measure, coagulated with alum, settled, chlorinated, filtered through a rapid-sand filter, and injected into the recharge well at an average rate of about $500 \mathrm{gpm}$ for 360 minutes. The turbidity of the injected water averaged $2 \mathrm{ppm}$. The average temperature of the injected water was $66^{\circ} \mathrm{F}$ and ranged from $63^{\circ}$ to $70^{\circ} \mathrm{F}$.

Test 18, utilizing a sand-packed well, was started on January 29, 1959. Surface water, treated similarly to that used during test 12, was injected at an average rate of $310 \mathrm{gpm}$ for 1,710 minutes. The turbidity of the injected water averaged slightly less than $3 \mathrm{ppm}$. Micro-organism control was not as effective as it had bene during test 12; the count averaged 10 per milliliter as compared to 8 in test 12 . The average temperature of the injected water was $43^{\circ} \mathrm{F}$, thus providing a large temperature differential when compared to the temperature of water injected during test 12.

Only slight differences, except in temperature, existed in the physical and chemical quality of the water injected during tests 12 and 18, and these were caused by minor variations in the method of water treatment. None of these slight differences are considered sufficient to have caused appreciable changes in injection characteristics. The rise in water level (fig. 3) observed during test 12 was thought to be the result of hydraulic buildup, and little if any of the rise was attributed to clogging of the recharge well and aquifer. Figure 4 shows the changes in water level observed in the first 6 hours of recharge during test 18. The shape of the hydrograph is similar to that shown in figure 3, and no clogging of the well was suspected. If no plugging occurred during test 18 and well characteristics were similar, the buildup in the recharge well at 400 minutes should be less, because the recharge rate was $190 \mathrm{gpm}$ less. Specific-capacity values should also reflect the rate difference. The value calculated at the higher rate should be less than that calculated at the lower rate because of increased turbulence losses. However, the figures show that this was not the case. The specific capacity at 400 minutes for $500 \mathrm{gpm}$ was $9.4 \mathrm{gpm}$ per ft. greater than that calculated at $310 \mathrm{gpm}$. 


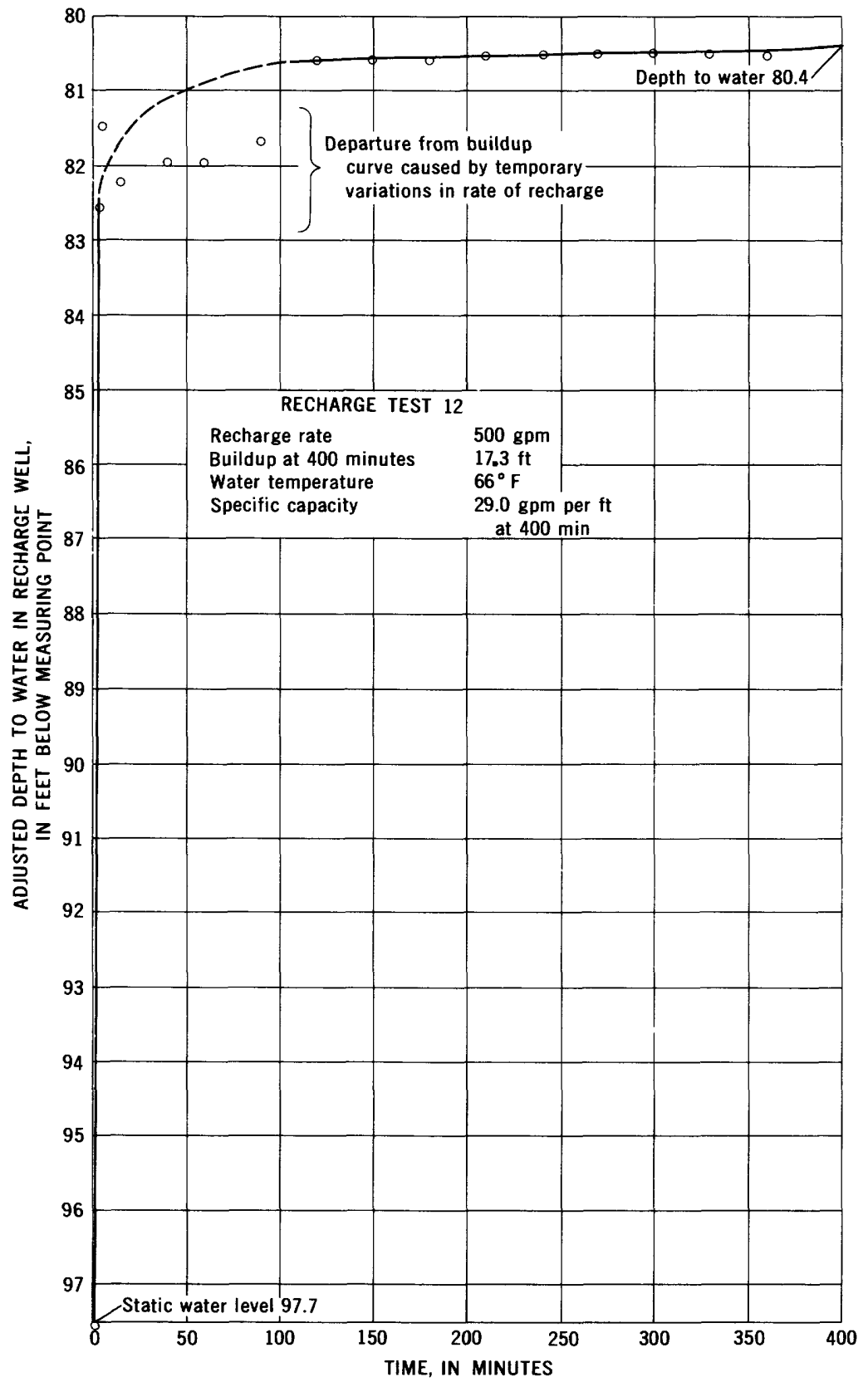

Figure 3.-Hydrograph of the recharge well during test 12. 
ARTIFICIAL RECHARGE, GRAND PRAIRIE REGION

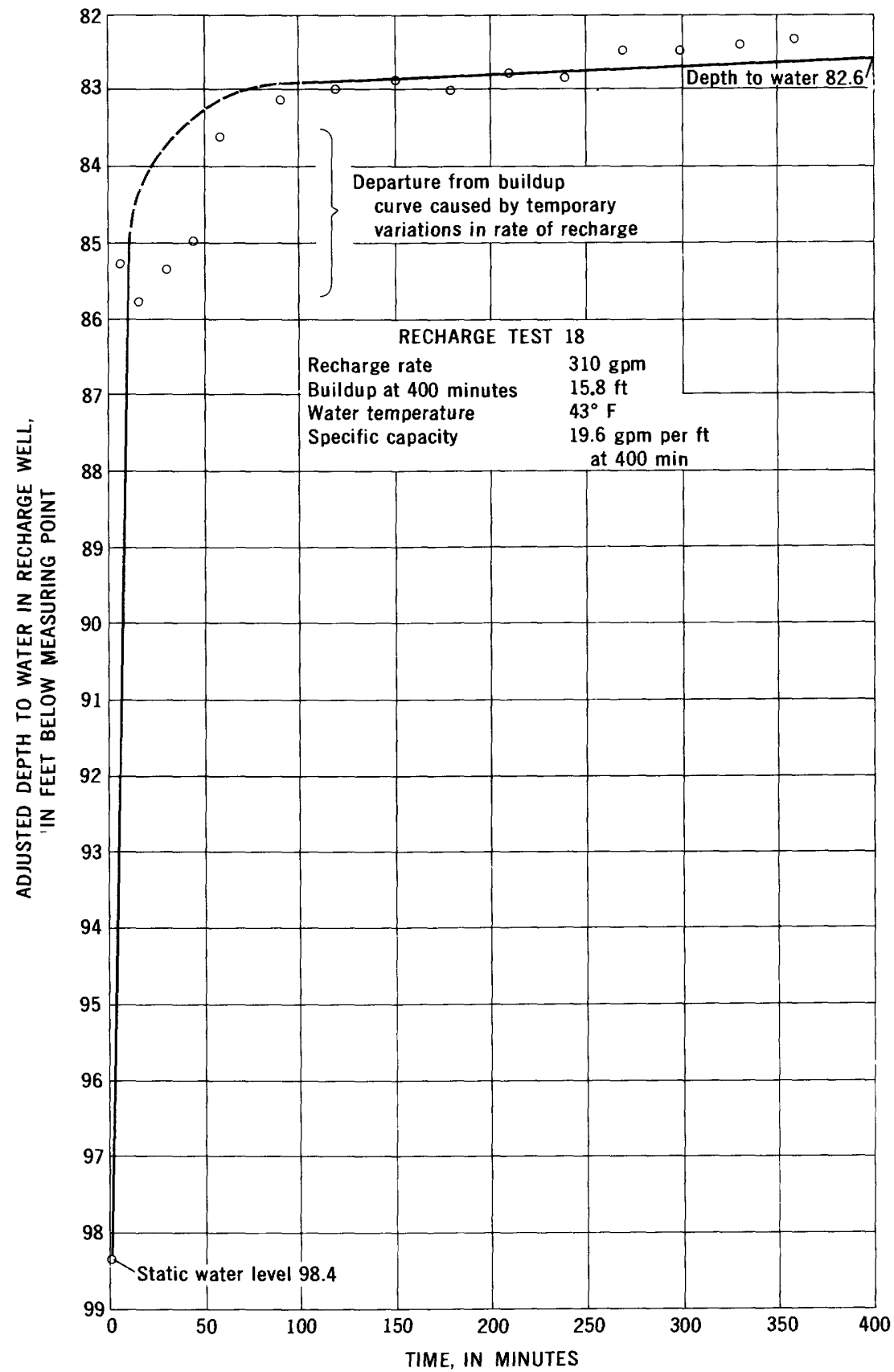

FIGURD 4.-Hydrograph of the recharge well during test 18. 
Because the well apparently was not plugged in either test, a check was made to determine whether or not viscosity differences caused by differences in water temperature might accourt for the different specific capacities and buildups. Temperature corrections were made using the factors given by Wenzel $(1942$, p. 62) where:

and

$$
P\left(43^{\circ} \mathrm{F}\right)=\frac{C_{t}(66)}{C t(43)} P\left(66^{\circ} \mathrm{F}\right),
$$

$$
\begin{aligned}
P & =\text { permeability } \\
C_{t} & =\text { conversion factor for temperatures indicated. }
\end{aligned}
$$

Specific capacity $(S c)$, neglecting turbulence losses, is directly proportional to the permeability.

Therefore,

$$
S c(43)=\frac{0.92}{1.31}(29.0)=20.3 \mathrm{gpm} \text { per } \mathrm{ft} .
$$

Thus, a specific capacity of $29 \mathrm{gpm}$ per $\mathrm{ft}$ as measured in test 12, with water at $66^{\circ} \mathrm{F}$, is adjusted to $20.3 \mathrm{gpm}$ per $\mathrm{ft}$ when corrected for viscosity differences for water at $43^{\circ} \mathrm{F}$. The specific capacity actually measured during test 18 was $19.6 \mathrm{gpm}$ per ft, only 0.7 foot less than the computed value. This indicates that the differences in specific capacity and buildup during the two tests probably were caused by changes in water viscosity.

Artificial recharge in any area would only be effective when a water supply is available for injection and not needed for direct application. In the Grand Prairie region, injection water would be available during the nongrowing winter season. Thus, if recharge through wells were to become a prevalent practice during winter months the average temperature of the water in the aquifer could be lowered. The following discussion serves to illustrate some problems arising when recharging with water that is colder than the native ground water.

An idealized geologic section in the Grand Prairie region is shown in figure 5. If the specific capacity of the well is $29 \mathrm{gpm}$ per $\mathrm{ft}$ and the water level in the well is drawn down to the top of the screen, theoretically it would be possible to pump $580 \mathrm{gpm}$ when the ground water has a temperature of $66^{\circ} \mathrm{F}$. If the temperature of the ground water is lowered to $43^{\circ} \mathrm{F}$ and the same pumping conditions as outlined above are imposed on the well, an additional 10 feet of saturation will be necessary to produce $580 \mathrm{gpm}$. This means that the first 10 feet of rise in water level in the aquifer brought about by recharge with cold water will be of no practical value in increasing the rate of production from a given well. To effect a general rise of 10 feet in the 


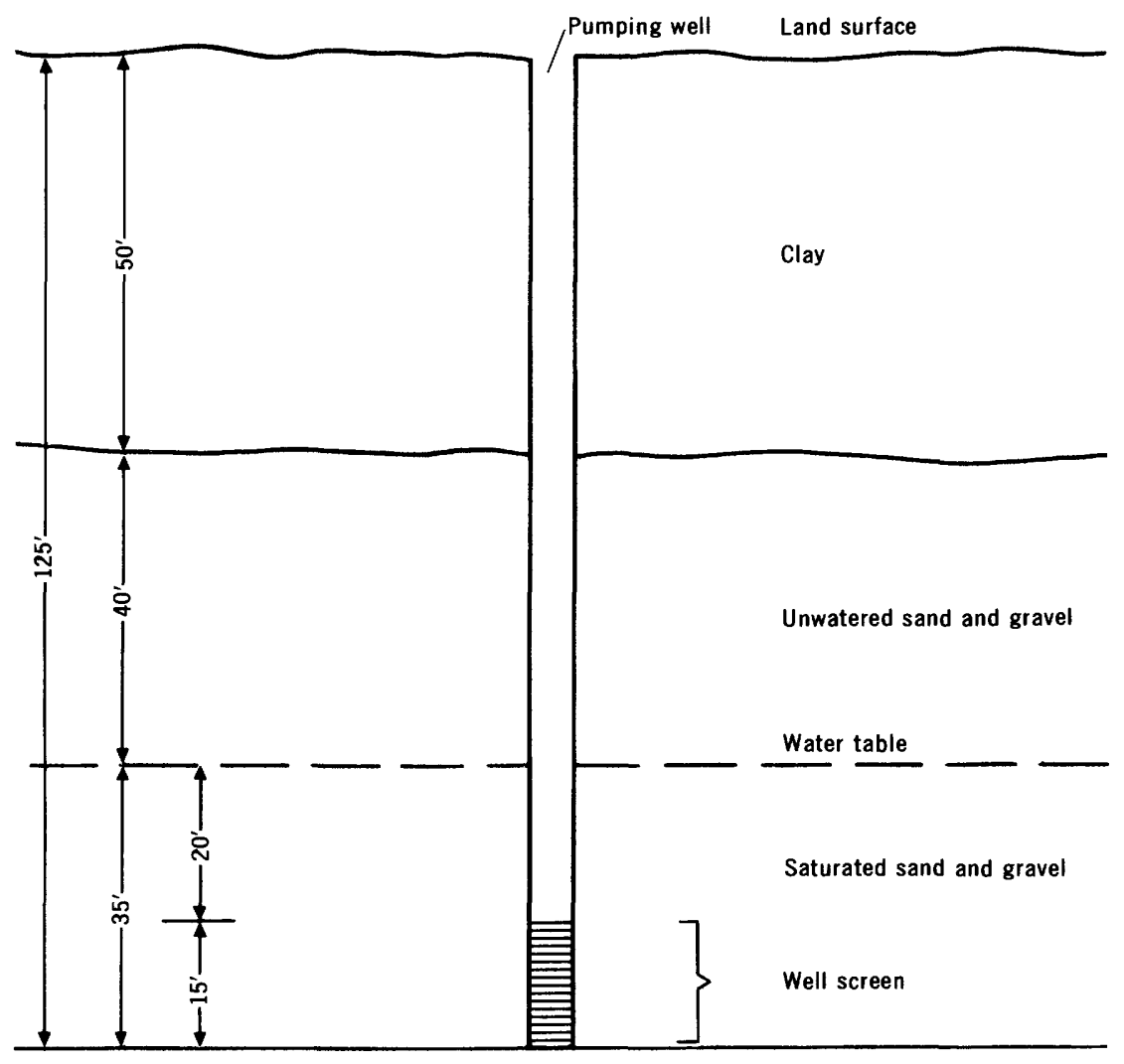

Clay

Figurb 5.-Ideallzed sketch of a typical well in the Grand Prairie region, Arkansas.

Grand Prairie aquifer will require many recharge wells injecting a large quantity of water. Therefore, results of recharge will be optimum when the injected water is the same temperature or warmer than the native ground water.

\section{SUSPENDED MATERIAI IN WATER}

Suspended material in the injected water was a major cause of well and aquifer clogging during recharge tests 8 and 9. A part of the data collected during these two tests is summarized below.

\begin{tabular}{|c|c|c|}
\hline & Test 8 & Test 9 \\
\hline $\begin{array}{l}\text { Temperature of native ground water } \\
\text { Temperature of injected water (average) } \\
\text { Temperature of injected water (range) } \\
\text { Specific capacity of recharge well before test } \\
\text { Specific capacity of recharge well after test }\end{array}$ & $\begin{array}{l}65^{\circ} \mathrm{F} \\
59^{\circ} \mathrm{F} \\
59^{\circ} \mathrm{F} \\
30 \mathrm{gpm} \text { per } \mathrm{ft} \\
27 \mathrm{gpm} \text { per } \mathrm{ft}\end{array}$ & $\begin{array}{l}61^{\circ} \mathrm{F} . \\
42^{\circ} \mathrm{F} \\
41-42^{\circ} \mathrm{F} \text {. } \\
27 \mathrm{gpm} \text { per } \mathrm{ft} \text {. } \\
12 \mathrm{gpm} \text { per } \mathrm{ft} .\end{array}$ \\
\hline
\end{tabular}


The depths to water inside and immediately outside the recharge well, the injection rate, and turbidity of the injected water during tests 8 and 9 for 210 minutes of recharge and shown graphically in figure 6 .
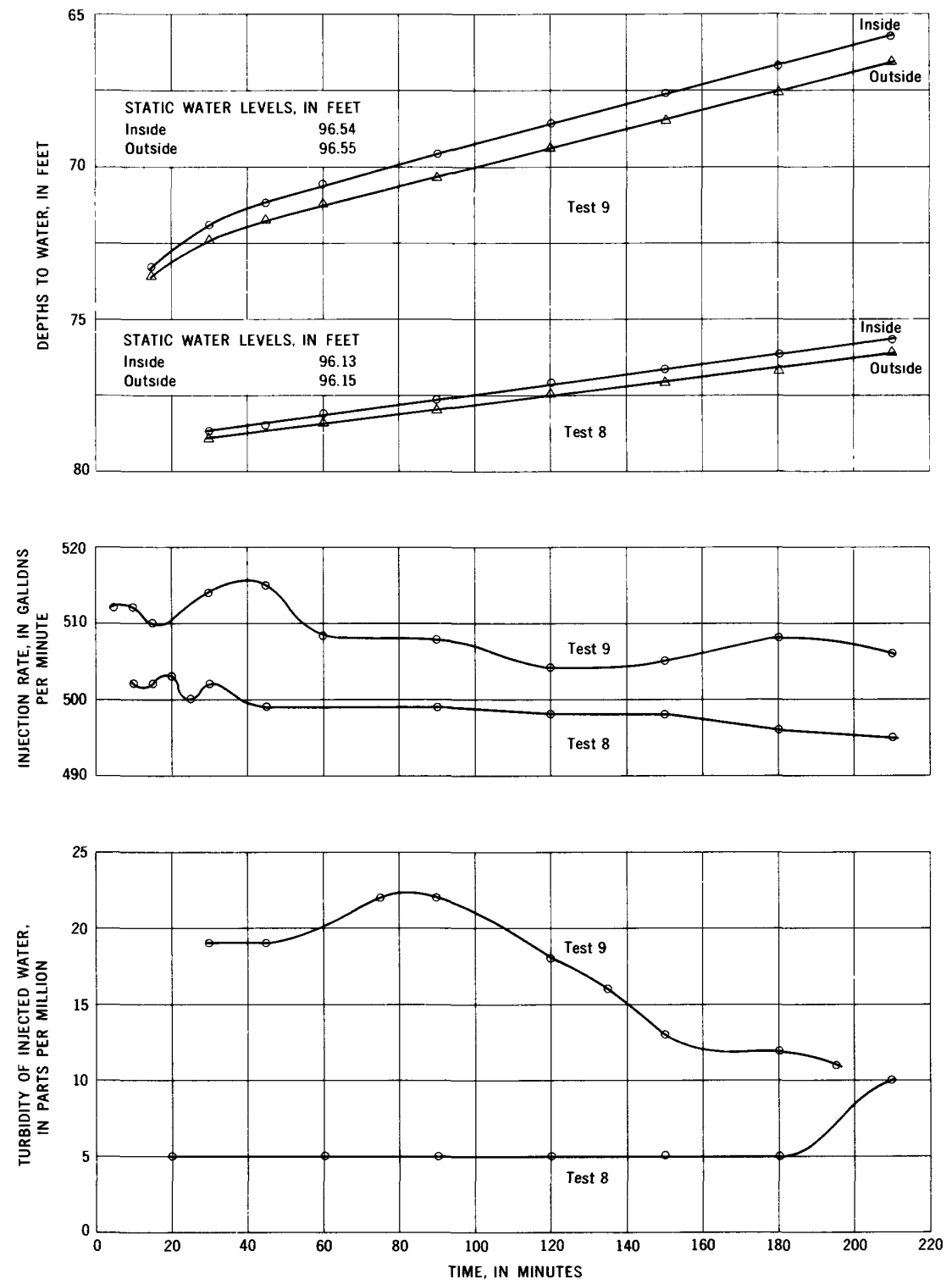

FigdRe 6.-Graphs showing the depths to water inside and immediately outside the recharge well, the injection rate, and the turbidity of the injected water during recharge tests 8 and 9. 
With the exception of the turbidity and temperature of the injected water, testing conditions during tests 8 and 9 were nearly alike. However, the injection rate during test 9 averaged approximately $14 \mathrm{gpm}$ higher than the injection rate during test 8 . On the basis of a potential injection specific capacity of $30 \mathrm{gpm}$ per $\mathrm{ft}$, the head inside the recharge well would be increased about 0.5 foot when recharging at a $14 \mathrm{gpm}$ higher rate. The temperature of the water injected during test 9 averaged $17^{\circ} \mathrm{F}$ cooler than that injected during test 8 . The injection head inside the recharge well would be increased by recharging with water of a higher temperature and consequently of a higher viscosity.

Figure 7 shows the difference between injection heads inside the

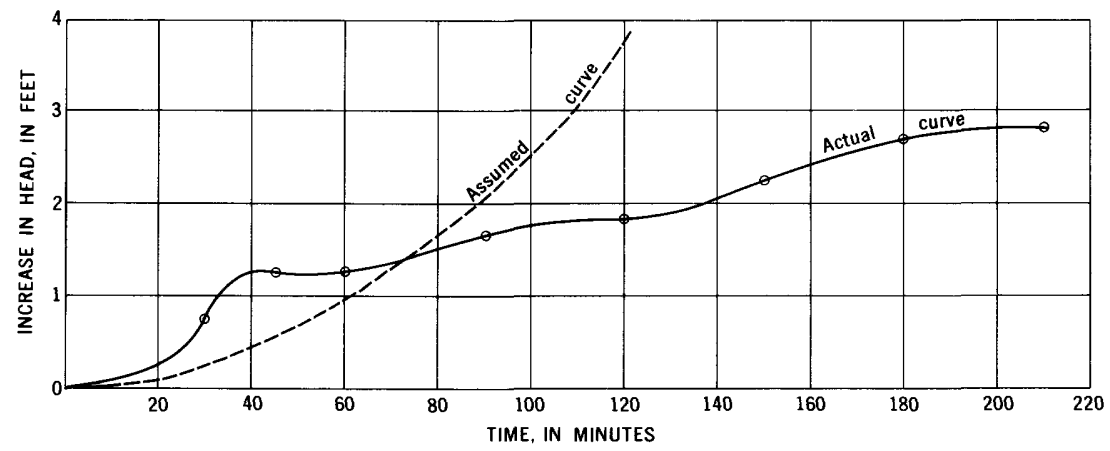

Figure 7.-Graph showing the difference in injection heads inside the recharge well caused by turbidity during tests 8 and 9.

recharge well during tests 8 and 9 after applying corrections for differences in specific capacity and water viscosity. This curve represents the amount of additional head that was required to move water into the aquifer during test 9 because the injection supply contained about three times more suspended material than the water injected during test 8 . The shape of the curve reflects the recharge rate, turbidity of the injected water, and the total quantity injected during the two tests. Had these three factors been constant for each respective test, it is assumed that the curve would have been shaped similar to a head-loss curve for a rapid-sand filter. (See dashed line, fig. 7.) The early increase and later decrease in turbidity content of the injected water during test 9 accounts for the flattening of the actual head-difference curve (fig. 6 ).

A comparison of specific capacities of the recharge well during tests 8 and 9 further illustrates that clogging increases with increased turbidity of the injected water. The specific capacity of the recharge well before test 8 was $30 \mathrm{gpm}$ per $\mathrm{ft}$ at the prevailing ground-water 
temperature of $65^{\circ} \mathrm{F}$. The specific capacity of the well after test 8 was $27 \mathrm{gpm}$ per $\mathrm{ft}$ at $59^{\circ} \mathrm{F}$ or about $29 \mathrm{gpm}$ per ft at $65^{\circ} \mathrm{F}$; a loss of about $1 \mathrm{gpm}$ per $\mathrm{ft}$. The specific capacity of the recharge well before test 9 was $27 \mathrm{gpm}$ per $\mathrm{ft}$ at $59^{\circ} \mathrm{F}$. After test 9 the specific capacity was $12 \mathrm{gpm}$ per $\mathrm{ft}$ at $42^{\circ} \mathrm{F}$ or about $16 \mathrm{gpm}$ per $\mathrm{ft}$ at $59^{\circ} \mathrm{F}$; a loss of approximately $11 \mathrm{gpm}$ per $\mathrm{ft}$. The higher turbidity of the water injected during test 9 (fig. 6) caused approximately a 40-percent loss of well specific capacity, whereas the turbidity of the injected water during test 8 caused only about a 3-percent loss.

Water levels were measured in an observation well about 5 feet from the recharge well during tests 8 and 9 at the same time measurements were made inside and immediately outside the recharge well. Hydrographs of the water levels in the well 5 feet from the recharge well were similar for both tests, indicating no relative difference in recharge-well and aquifer plugging. However, comparisons of the specific capacities of the recharge well after tests 8 and 9 showed that the recharge well and aquifer were more severely plugged during test 9 than during test 8 . Also, plugging by suspended material was demonstrated by a comparison of the water levels inside and immediately outside the recharge well (fig. 6). After 60 minutes of injection during test 8 , the head difference between the water level inside and outside of the recharge well was 0.26 foot and after 210 minutes of injection, the head difference was 0.44 foot. During test 9 , this head difference was 0.52 foot after 60 minutes recharge and 0.96 foot after 210 minutes. Apparently, the suspended material was trapped on the recharge well screen and in the aquifer between the recharge well and the observation well 5 feet distant.

The Millipore filter apparatus, described in another report in this series (Sniegocki, Bayley, and Engler, 1963), was used to collect samples of suspended solids from the water injected during tests 18 and 19. The percentage composition of the samples and the estimated quantity of suspended solids entering the recharge well during these two tests are shown in the following table:

\begin{tabular}{|c|c|c|c|c|c|c|c|}
\hline \multirow{2}{*}{ Test } & \multirow{2}{*}{ Date } & \multirow{2}{*}{$\begin{array}{l}\text { Water } \\
\text { injeeted } \\
\text { (gallons) }\end{array}$} & \multirow{2}{*}{$\begin{array}{c}\text { Sus- } \\
\text { pended } \\
\text { solids } \\
\text { injected } \\
\text { (pounds) }\end{array}$} & \multicolumn{4}{|c|}{ Percentage composit1 $n$} \\
\hline & & & & $\begin{array}{l}\text { Organic } \\
\text { matter }\end{array}$ & $\mathrm{Fe}_{2} \mathrm{O}_{3}$ & $\mathrm{Al}_{2} \mathrm{O}_{3}$ & $\begin{array}{l}\text { Clay and } \\
\text { other }\end{array}$ \\
\hline 18.- & $\begin{array}{l}1 / 31 / 59 \\
2 / 1 / 59 \\
2 / 19959 \\
2 / 20 / 59 \\
2 / 22 / 59 \\
2 / 23 / 59 \\
2 / 24 / 59\end{array}$ & $\begin{array}{l}131,500 \\
131,400 \\
131,800 \\
131,700 \\
131,150 \\
130,720 \\
131,500\end{array}$ & $\begin{array}{r}15 \\
8 \\
238 \\
217 \\
744 \\
196 \\
241\end{array}$ & $\begin{array}{l}85.5 \\
68.5 \\
39.5 \\
35.0 \\
76.0 \\
27.0 \\
49.6\end{array}$ & $\begin{array}{r}0.4 \\
.6 \\
.7 \\
6.1 \\
.5 \\
1.6 \\
4.0\end{array}$ & $\begin{array}{r}3.4 \\
.2 \\
25.9 \\
25.9 \\
3.8 \\
1.1 \\
2.7\end{array}$ & $\begin{array}{l}10.7 \\
30.7 \\
59.7 \\
33.0 \\
19.7 \\
70.3 \\
43.7\end{array}$ \\
\hline
\end{tabular}




\section{MICRO-ORGANISMS}

Actual injection data are not available to evaluate the clogging effect of micro-organisms when recharging through wells. However, general observations were made of the kinds and numbers of microorganisms in the recharge water, and an inferrence of their effect on a recharge well may be made by drawing upon experience with rapid-sand filters.

Water-treatment plants for municipal water supplies carefully control the micro-organisms in the raw-water supply and the treatment process, because certain micro-organisms impart objectionable tastes and odors to water. Without adequate control, distribution lines will accumulate slime deposits that greatly restrict passage of water. In addition, certain micro-organisms such as Synedra Ulna (Hale, 1954, p. 34) quickly clog a rapid-sand filter, causing shortened filter runs and increased water-treatment costs.

Preliminary analyses of the raw surface water used for recharge showed several forms of microscopic organisms. The most common genera identified were Asterionella, Synedra Ulna, Pediastrum, Coelosphaeruim, Euglena, Anuraea, and Daphnia (Hale, 1954, p. 3243). The number of micro-organisms before and after water treatment with copper sulfate, alum, and filtration is listed below.

\begin{tabular}{|c|c|c|c|}
\hline Sampling point & Treatment & $\begin{array}{l}\text { Number of } \\
\text { organisms per } \\
\text { milliliter }\end{array}$ & Remarks \\
\hline $\begin{array}{l}\text { Distribution canal from reser- } \\
\text { voir. } \\
\text { Settling canal at filter intake.- } \\
\text { Filter effluent line. }\end{array}$ & $\begin{array}{l}\text { Copper sulfate and alum. } \\
\text { Copper sulfate, alum, } \\
\text { and filtration. }\end{array}$ & $\begin{array}{r}916,368,878,428 \\
271,271,347 \\
8,7,9,7\end{array}$ & $\begin{array}{l}\text { Raw surface water, many } \\
\text { moving organisms. } \\
\text { No organisms observed mov- } \\
\text { ing. } \\
\text { Completely treated water. }\end{array}$ \\
\hline
\end{tabular}

Water containing as many as 1,000 micro-organisms per milliliter was injected into the aquifer during several recharge tests. Water recovered from the recharge well after such tests frequently was green colored and had a foul odor during the first few minutes of pumping. Samples of the recovered water contained many fragmental remains of micro-organisms.

If water is injected into an aquifer through wells without regard for micro-organisms, the aquifer could be destroyed as a source for domestic water. Many recharge wells operating over a long period eventually could cause the water in the aquifer to become 
unpalatable, assuming that water with a high micro-organism count could be satisfactorily injected without clogging the well and aquifer. In addition, siliceous shells characteristic of many genera would fill interstitial space in the aquifer, reducing permeability.

\section{INTERPRETATION OF RECHARGE DATA}

When water is withdrawn for a given period at a given rate from a confined, isotropic, homogeneous aquifer of infinite areal extent through a well, the piezometric surface in the well and aquifer will decline and form a cone of depression around the well. The hydraulic character of the aquifer, the withdrawal rate, and the pumping period are the principal factors controlling the size and shape of the cone of depression. Conversely, if water the same temperature as the native ground water is injected into the aquifer through the well, the piezometric surface will build up around the well and form a cone of elevation. Theoretically, the cone of elevation should be the mirror image of the cone of depression for the given period of time at the given rate. If the cone of elevation has a steeper gradient than the cone of depression, it may be assumed that the permeability of the aquifer has been decreased by injecting water that causes plugging of the well and aquifer. A comparison of hydraulic constants calculated for the aquifer from drawdown and buildup water-level data should provide a means for quantitatively evaluating clogging effects; that is, separation of hydraulic buildup from plugging buildup.

Observation wells at a distance of twice the thickness of the saturated section of the aquifer from the pumping well provide access for obtaining water-level data that generally are satisfactory for calculating hydraulic constants of the aquifer. However, in the Grand Prairie recharge tests, water-level data from distant observation wells were of little value in separating hydraulic buildup from plugging buildup. Plugging generally occurred within a few feet of a recharge well. As long as the injection rate was constant the hydraulic values, calculated from recharge water-level data obtained in distant observation wells, were about the same as those obtained from drawdown water-level data, despite the fact that plugging was occurring in the recharge well and aquifer.

This is demonstrated by the following calculation of hydraulic constants for the aquifer from water-level data obtained during recharge test 13 . The hydrograph (fig. 8) was used to calculate the 


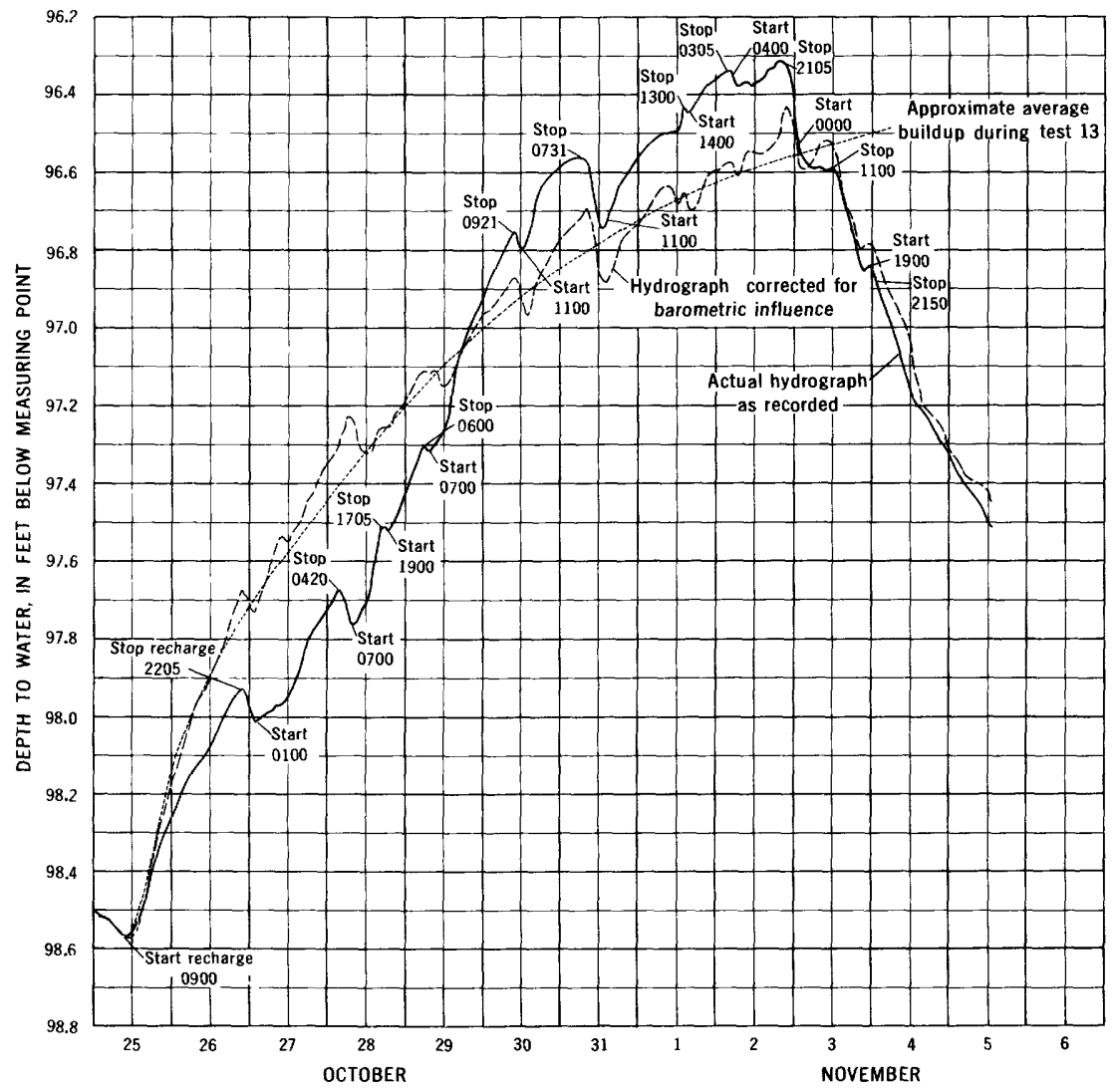

Fiourw 8. - Hydrograph of the water level in an observation well 200 feet from the recharge well.

coefficient of transmissibility $(T)$ and the coefficient of storage $(S)$ of the aquifer in which

$T$ is the number of gallons of water a day, at the prevailing temperature, transmitted through each mile strip extending the height of the aquifer, under a hydraulic gradient of 1 foot to the mile; $S$ is the volume of water an aquifer will release from, or take into, storage per unit surface area of the aquifer per unit change in the component of head normal to that surface. 
Expressed mathematically according to Theis (1935),

$$
T=\frac{114.6 Q W(u)}{s_{c}} \text { and } \mathrm{S}=\frac{u T}{1.87 r^{2} / t}
$$

in which

$T=$ coefficient of transmissibility in gallons per day per foot

$S=$ coefficient of storage (dimensionless)

$Q=$ pumping rate, in gallons per minute

$t=$ time in days

$s_{c}=$ corrected drawdown, recovery, buildup or refluence, in feet

$r=$ distance of observation well from the pumped well, in feet

$u=\frac{1.87 r^{2} S}{T_{t}}$

$$
W(u)=-0.577216-\log _{e} u+u-\frac{u^{2}}{2 \cdot 2 !}+\frac{u^{3}}{3 \cdot 3 !}-\frac{u^{4}}{4 \cdot 4 !} \cdots
$$

or the so-called well function of $u$.

Replotting the approximate water-level buildup from figure 8 according to the Theis graphical method (fig. 9) and substituting values into the proper formulas, the coefficient of transmissibility was about $71,000 \mathrm{gpd}$ per $\mathrm{ft}$ and the coefficient of storage was about 0.30 after 13,140 minutes of injection. The coefficient of transmissibility obtained from water-level data collected while pumping the recharge well before any recharge tests were made was about $70,000 \mathrm{gpd}$ per $\mathrm{ft}$ and the coefficient of storage was about 0.18 at the end of 1,920 minutes of discharge (Sniegocki, 1963a). Plugging is not apparent from a comparison of the hydraulic constants calculated for the aquifer from recharge data collected during test 13 and pumping data collected during an aquifer test.

However, the specific capacity of the well before and after recharge test 13 was 33 and $18 \mathrm{gpm}$ per $\mathrm{ft}$, respectively. The temperature of the water injected during test 13 averaged $57^{\circ} \mathrm{F}$, and a correction for waterviscosity differences adjusted the post-test specific capacity to about $22 \mathrm{gpm}$ per $\mathrm{ft}$. During the 12,142-minute injection period of test 13 the specific capacity of the recharge well was lowered about 30 percent, proving conclusively that the well and aquifer were partly plugged during the test.

During injection tests, measurements of water levels were made inside and immediately outside the recharge well and in an observation well 5 feet from the recharge well. Hydraulic constants calculated for the aquifer from these data are apparent values and are not valid this 


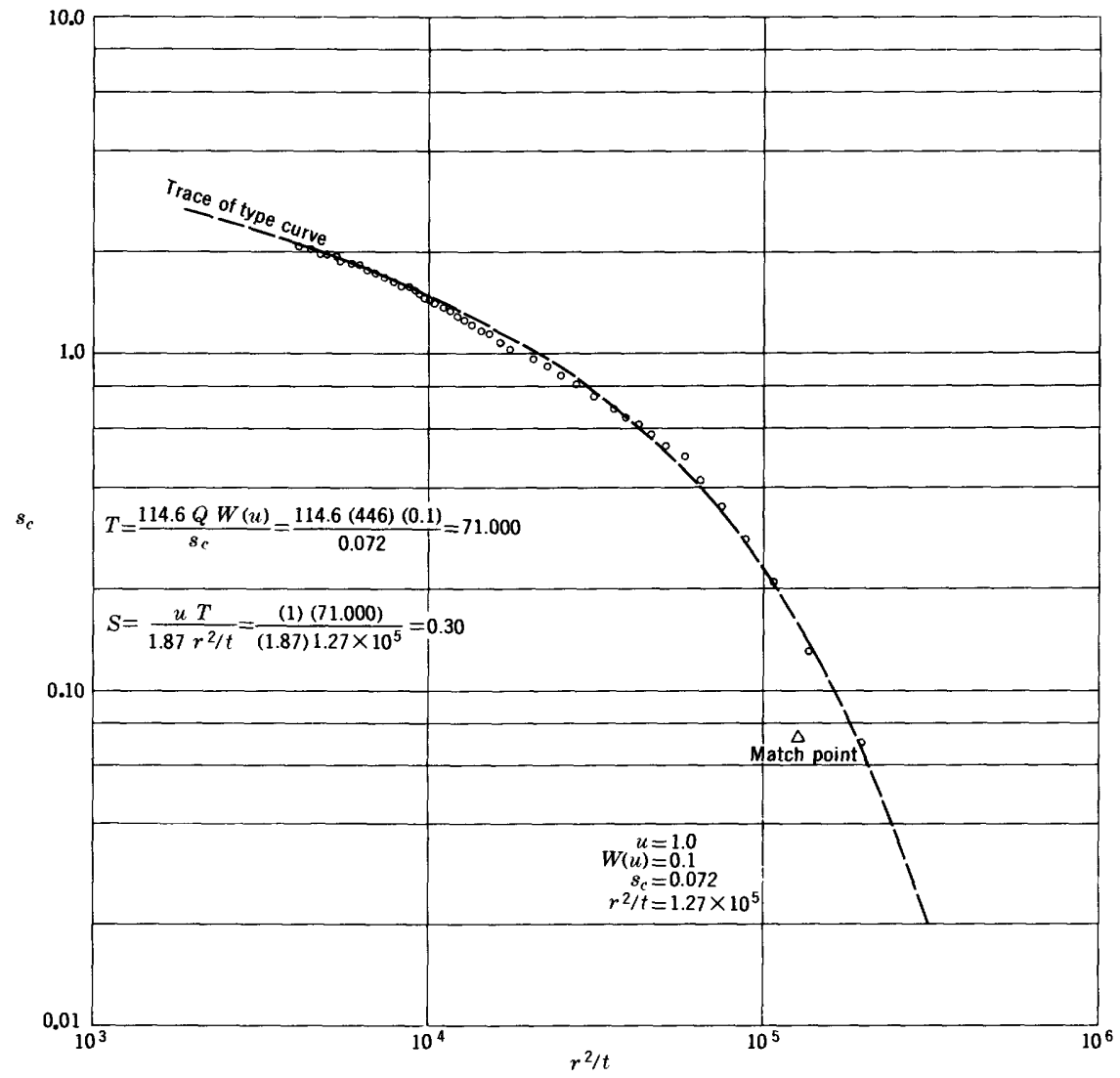

Froure 9.-Logarithmic plot of $8^{c}$ versus $r^{2} t$ during test 13, from data obtained from an observation well 200 feet from the recharge well.

close to the recharge well, principally because the effective radius of the well cannot be determined. Yet, to a great extent, aquifer hydraulics control the head or rate of buildup in the recharge well at a given injection rate and period. Thus, a comparison of the shapes of the cones of elevation and a comparison of apparent hydraulic constants for the aquifer should provide a means of determining what relative part of the buildup is caused by plugging. For example, if the rate of buildup for the same rate and period of recharge was greater in one injection period than in another, it might be concluded that plugging was greater in the injection period in which the rate of buildup or total buildup was greater. However, this conclusion may be incorrect because all factors influencing buildup have not been considered. An examination of theoretical concepts and recharge-test data will illustrate some of the factors that should be considered when interpreting water-level changes in and near the recharge well. 
Theoretical time-drawdown and time-buildup hydrographs of waterlevel changes in a recharge well at the site of this study are shown in

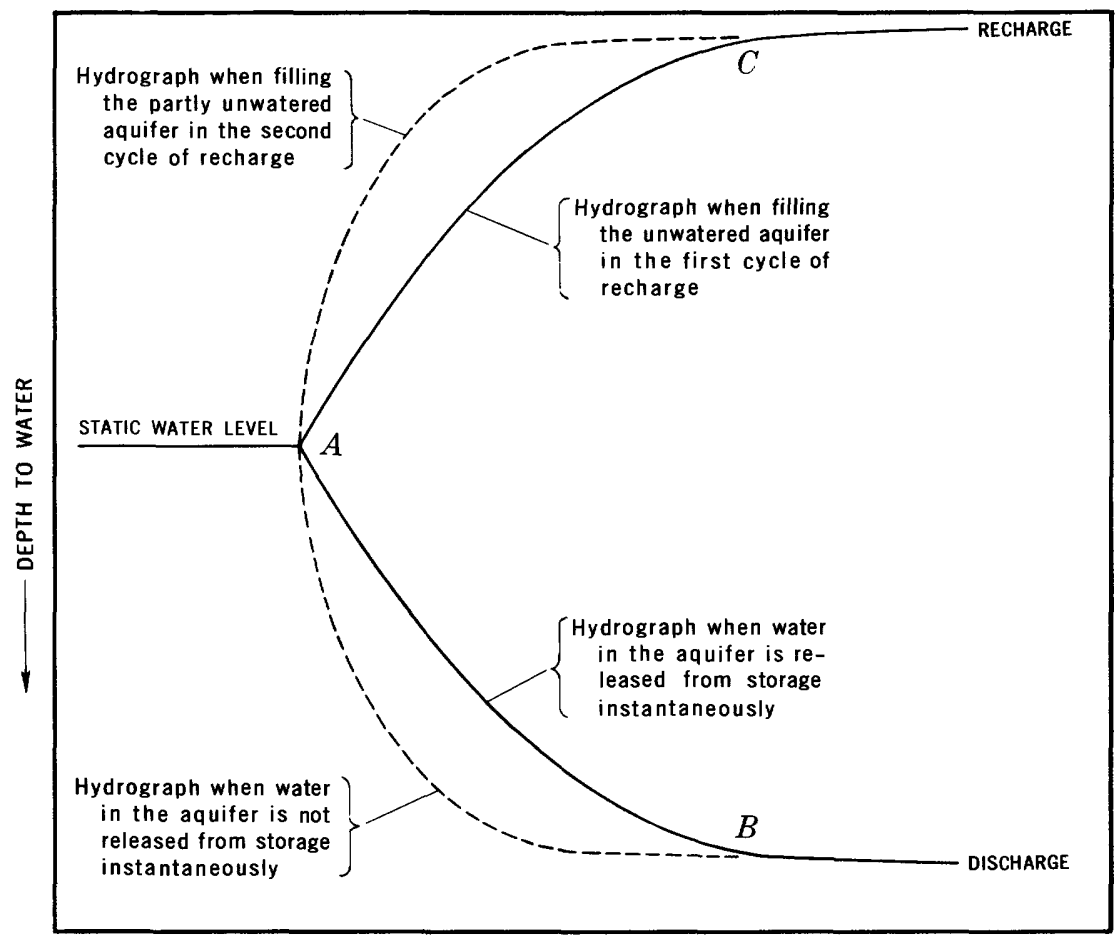

TIME

Figure 10.-Theoretical hydrographs of water levels in a recharge well in the Grand Pralrle region, Arkansas.

figure 10. The hydrographs are based on work by Hantush (1960, p. 3,722), Smith (1961), and data collected during discharge and recharge tests.

The dashed line, $A-B$ (fig. 10), represents the water level in a recharge well under discharge conditions. After sufficient time has elapsed, the observed drawdown will be the same as it would have been had the water been released from storage instantaneously.

Field data supporting this premise were collected during an aquifer test at the recharge site. The coefficient of storage increased from about 0.15 at 1,020 minutes to 0.18 at 1,920 minutes (Sniegocki, 1963a). Other aquifer tests in the Grand Prarie region showed an increase in the coefficient of storage with time and that an absolute value of about 0.30 would not be obtained until pumping had continued for more than 100 days (Engler and others, 1945, p. 42).

The initial rate of drawdown in the dashed line, $A-B$ (fig. 10), is greater than the initial rate of drawdown in the solid line, $A-B$, be- 
cause water is not released from storage instantaneously. If the cone of depression formed in the aquifer by pumping is maintained for a sufficient period of time, slow drainage of pendular and funicular water in the cone will be more complete.

The solid line, $A-C$ (fig. 10), represents the water level in a recharge well under injection conditions when the unwatered part of the aquifer is filled the first time after a long period of time in the unwatered state. The coefficient of storage calculated from observation-well data should not vary with time but should be an absolute value. This conclusion is supported by the data shown in figures 8 and 9 . The coefficient of storage was 0.30 after cyclical recharge for about 9 days; whereas, in the discharge situation, a value of 0.30 would not be obtained until pumping had continued for more than 100 days.

The dashed line, $A-C$ (fig. 10), represents the water levels that would be observed in the recharge well if recharge were stopped and started again with only a few minutes' interruption between recharge periods. The water level would build up to its previous position more rapidly than during the first cycle of recharge.

The rapid buildup rate in the second cycle of recharge is caused by pendular and funicular water remaining in the previously formed cone of elevation and nonequilibrium conditions in the aquifer, or, what might be termed residual hydraulic head. (See pl. 1.)

The rapid rate of buildup of the water level in the observation well 5 feet from the recharge well in the second and succeeding cycles of recharge $\left(B^{\prime}-K^{\prime}\right.$, pl. 1) was caused by residual hydraulic head and pendular and funicular water remaining in the cone of elevation formed in the first cycle of injection. After the new cone becomes large enough to saturate a part of the aquifer uninfluenced by pendular and funicular water, the rate of buildup slackens. The slope of the buildup becomes the same as that near the end of the preceding cycle of injection.

The rapid rate of buildup of the water level inside the recharge well in the second and succeeding cycles of recharge $(B-K$, pl. 1$)$ was caused by plugging, in addition to residual hydraulic head and pendular and funicular water. The water levels as represented by $B-K$ (pl. 1) rise rapidly to the level recorded in the preceding cycle of injection but do not assume the same slope.

\section{CONCLUSIONS}

The principal causes of clogging of the recharge well and aquifer observed in this investigation were air entrainment, suspended material and micro-organisms in the recharge water; and precipitates caused by chemical reactions between the ground water, aquifer, and recharge water. Other problems related to operation of the recharge 
wells included the effect of injecting water that was colder than the native ground water; weather conditions; and distinguishing between buildup of the water level caused by hydraulic characteristics of the aquifer and buildup caused by plugging of the well.

Air entrainment during recharge can be eliminated by installing a valve at the bottom of the injection pipe inside the recharge well and careful connection of all joints in the well intake pipe (Sniegocki and Reed, 1963). The release of dissolved gases from recharged water has a plugging effect similar to air entrainment. However, gas binding caused by the release of dissolved gases can be minimized by recharging with water that is the same temperature or warmer than the native ground water. Recharge with water that is the same temperature or warmer than the native ground water also will preclude any undesirable water-viscosity changes.

Observation-well spacing, as generaly used in aquifer tests, is not suitable for obtaining water-level data that will show early plugging. As long as the injection rate is constant, plugging head in the recharge well is not reflected in distant water-level changes. Water-level data must be collected in and near the recharge well if plugging is to be detected as early as possible.

Results of this study show that recharge water-level data may be satisfactory for calculating absolute values of hydraulic constants of an aquifer. If such a procedure is reliable and the field situation readily adaptable for a recharge test, the testing period generally required to determine absolute hydraulic constants may be shortened as much as 90 percent.

Water containing suspended material could not be successfully recharged through wells for an extended period during this study. Suspended material was trapped on the well screen and in the aquifer, an removal by well redevelopment, though possible, often was difficult.

In an aquifer comprising very coarse material, in which a well could be constructed with large openings, suspended particles in injected water would tend to move through interstitial spaces and clogging would be minimized. However, if water containing suspended particles is successfully injected for an extended period certain undesirable effects are possible. The suspended material will settle some distance from the well, remain in suspension, or a part will settle and a part remain in suspension.

If the suspended particles settle in the aquifer they will reduce aquifer permeability and eventually occupy interstitial space. The time required to clog the aquifer and the volume clogged are the principal factors to be considered in determining the feasibility of recharge in this situation.

If the suspended material does not settle in the aquifer, eventually any water that is reclaimed from the aquifer will contain suspended 
material. For most purposes the suspended material must be removed before the reclaimed water can be used. For example, although much of the reclaimed water may be used for irrigation in which suspended material may not be objectionable, the same aquifer may be a source of water for domestic use. Each domestic water-supply system would require a means for removing suspended material from the reclaimed water.

Under certain recharge conditions, the suspended material must be removed from the injection supply or recharge will not successful for any practical period. Under other recharge conditions, a large volume of the aquifer may be destroyed by clogging, or the water in the aquifer will be contaminated with suspended material over a large area. The consequences of recharging through wells with water contaminated with chemicals, micro-organisms, and bacteria are much the same as recharging through wells with water containing suspended material. Therefore, it is recommended that recharge through wells be done with water that would meet public health standards.

Standard water-treatment practices may be used to treat recharge water. The cost of treating the recharge supply depends upon the kind and amount of suspended material and micro-organisms in the water, chemical and physical characteristics of the water, and the equipment and associated facilities used in the treatment process. Thus, if recharge is done with treated water, the treatment cost is a principal factor in determining the economic feasibility of recharge. However, the economic feasibility of recharge through wells cannot be based only on the cost of water treatment. The reclaimed use of the injected water may greatly modify or offset the cost of water treatment and, therefore, also must be considered as a principal factor in determining the economic feasibility of recharge through wells.

The results of these studies indicate that under present economic conditions (1962), the cost of water treatment required to minimize clogging and the use of the recharged water for rice irrigation makes recharge through wells economically unfeasible as a means of solving the ground-water problem in the Grand Prairie region.

\section{REFERENCES CITED}

California Water Pollution Control Board, 1954, Report on the investigation of travel of pollution: Sacramento, Calif., Pub. 11, 218 p.

Engler, Kyle, Bayley, F. H., 3d, and Sniegocki, R. T. 1963, Studies of artificial recharge in the Grand Prairie region, Arkansas-environment and history: U.S. Geol. Survey Water-Supply Paper 1615-A. (In press.)

Engler, Kyle, Thompson, D. G., and Kazmann, R. G.; 1945, Ground-water supplies for rice irrigation in the Grand Prairie region, Arkansas: Arkansas Univ. Agr. Expt. Sta. Bull. 457, 56 p. 
Gardescu, I. I., 1930, Behavoir of gas bubbles in capillary spaces: Am. Inst. Mining Metall. Engineers Tech. Pub. 306, 20 p.

Hale, F. E., 1954, The use of copper sulphate in control of microscopic organisms : Phelps Dodge Refining Co., New York, $44 \mathrm{p}$.

Hantush, M. S., 1960, Modification of the theory of leaky aquifers : Jour. Geophys. Research, v. 65, no. 11, p. 3713-3725.

Orlob, G. T., and Radhakrishna, G. N., 1958, The effects of entrapped gases on the hydraulic characteristics of porous media: Am. Geophys. Union Trans., v. 39, no. 4, p. 648-659.

Smith, W. O., 1961, Mechanism of gravity drainage and its relation to specific yield of uniform sands: U.S. Geol. Survey Prof. Paper 402-A, 12 p.

Smith, W. O., and Crane, M. D., 1930, The Jamin effect in cylindrical tubes: Am. Chem. Soc. Jour., v. 52, p. 1345-1349.

Sniegocki, R. T., 1963a, Hydrogeology of a part of the Grand Prairie region, Arkansas: U.S. Geol. Survey Water-Supply Paper 1615-B. (In press.)

,$- 1963 \mathrm{~b}$, Geochemical aspects of artificial recharge in the Grand Prairie region, Arkansas: U.S. Geol. Survey Water-Supply Paper 1615-E. (In press.)

Sniegocki, R. T., Bayley, F. H., 3d, and Engler, Kyle, 1963, Equipment and controls used in studies of artificial recharge in the Grand Prairie region, Arkansas: U.S. Geol. Survey Water-Supply Paper 1615-C, C1-C39.

Sniegocki, R. T., and Reed, J. E., 1963, Principles of siphons with respect to artificial-recharge studies in the Grand Prairie region, Arkansas: U.S. Geol. Survey Water-Supply Paper 1615-D, D1-D19.

Theis, C. V., 1935, The relation between the lowering of the piezometric surface and the rate and duration of discharge of a well using ground water storage: Am. Geophys. Union Trans., v. 16, p. 519-524.

Wenzel, L. K., and Fishel, V. C., 1942, Methods for determining permeability of water-bearing materials, with special reference to discharging-well methods, with a section on direct laboratory methods and bibliography on permeability and laminar flow: U.S. Geol. Survey Water-Supply Paper 887, $192 \mathrm{p}$. 